\title{
Risk Factors for Perineal Tears Among Women Delivering at Kawempe National Referral Hospital, Uganda: A Case Control Study
}

Gwazo Mathias ( $\sim$ mathiasetal@gmail.com )

Makerere University

Barageine Justus Kafunjo

Makerere University

Kazibwe Lawrence

Kawempe National Referral Hospital Uganda

\section{Research Article}

Keywords: Vaginal delivery, Perineal tear, Risk factors, Kawempe

Posted Date: March 10th, 2021

DOI: https://doi.org/10.21203/rs.3.rs-263353/v1

License: (a) (i) This work is licensed under a Creative Commons Attribution 4.0 International License.

Read Full License 


\section{Abstract}

Background: Perineal tear is a common complication of vaginal delivery with a significant negative impact on the quality of life. The condition commonly occurs among un-attended deliveries or those conducted by unskilled birth attendant especially in low-resource settings. The risk factors for perineal tear were not known at Kawempe Hospital. We conducted this study to determine the risk factors for perineal tear among women delivering at Kawempe National Referral Hospital, Uganda.

Methods: This was a case control study that was conducted among women who had vaginal delivery at Kawempe National Referral Hospital from $20^{\text {th }}$ December 2019 to $5^{\text {th }}$ February 2020. Data on sociodemographic, maternal, fetal and provider characteristics were collected using an interviewer's administered questionnaire. Risk factors were determined using bivariate and multivariate logistic regression analysis.

Results: The risk factors for perineal tear were: maternal age of $\geq 20$ years (AOR $=7.24,95 \%$ $\mathrm{Cl}=2.28-23.00, \mathrm{P}<0.001)$, delivery by assistant nursing officer $(\mathrm{AOR}=16.39,95 \% \mathrm{Cl}=5.74-46.81, \mathrm{p}$ $<0.001)$, primiparity ( $A O R=12.46,95 \% \mathrm{Cl},=3.41-45.52, \mathrm{P}<0.001)$, single marital status ( $A O R=14.39$ 95\%, $\mathrm{Cl}=4.28-48.39, \mathrm{P}<0.001)$, precipitate labour $(\mathrm{AOR}=7.8,95 \% \mathrm{Cl}=2.21-27.55, \mathrm{P}<0.001)$, assisted vaginal delivery $(\mathrm{AOR}=8.33,95 \% \mathrm{Cl}=1.43-48.6, \mathrm{P}<0.019)$, fetal weight $\geq 3.5 \mathrm{Kg}(\mathrm{AOR}=2.19,95 \% \mathrm{Cl}=1.06$ $4.53, \mathrm{P}<0.033)$, duration of active first stage of labour $\geq 8$ hours ( $\mathrm{AOR}=12.65,95 \% \mathrm{Cl}=5.65-28.25, \mathrm{P}<0.001)$ and duration of second stage of labour $>1$ hour

$(A O R=10.2195 \% \mathrm{Cl}=3.32-31.41, \mathrm{P}<0.001)$.

Conclusions. The risk factors for perineal tear during vaginal delivery at Kawempe National Referral Hospital were: maternal age $\geq 20$ years, delivery by assistant nursing officer, primiparity, single marital status, precipitate labour, assisted vaginal delivery, fetal weight $\geq 3.5 \mathrm{~kg}$, duration of active first stage of labour $\geq 8$ hours, duration of second stage of labour $\geq 1$ hours.

\section{Background}

A perineal tear is defined as a break in the continuity of either the perineal skin, mucosa, muscles/ connective tissues, anal sphincter complex and or rectal mucosa [1]. It is estimated that up to $85 \%$ of women experience perineal tear at one time during vaginal delivery [2], with undesirable maternal outcomes [3]. These perineal tears especially the severe ones are most common among deliveries that are either unattended or conducted by un skilled birth attendants [4]. There is some evidence that the incidence of severe perineal tear may be increasing worldwide [5], but it is unclear if this is due to improved recognition, reporting or actual rise. A study at Mbarara Teaching Hospital in South Western Uganda indicated the incidence of $6 \%$ for severe perineal tears among vaginal deliveries [4]. In relation to this, a survey by WHO in 2014 reported that severe perineal tear occurred in up to $15 \%$ of deliveries in Philippine [6]. The overall prevalence of perineal tear was $36.5 \%$ at Mulago National Referral Hospital, 
Kampala Uganda [7] . In other study, second degree perineal tears occured up to $31 \%$ of vaginal deliveries [8]. Women who sustain birth related perineal injuries are at risk of undesirable maternal outcomes. The most common outcomes are, postpartum hemorrhage, perineal pain, sexual dysfunction, rectovaginal fistula and anal incontinence

The risk factors for perineal tear consistently highlighted in previous studies are:-duration of second stage of labour $>1$ hours, [5], [9], [10], nulliparity [6], [11], fetal weight $\geq 3.5 \mathrm{~kg}$ [12], [4], fetal weight $\geq 4.0 \mathrm{Kg} \mathrm{[6],} \mathrm{[9],}$ assisted vaginal delivery [9], [6], [13], occiput posterior position [14], [15],

precipitate labour [13], [16], and fetal head circumference $>35 \mathrm{~cm}$ [17]. Episiotomy has been linked to occurrence of perineal tear, but with conflicting reports. In this context, the procedure has been reported to be protective against tears [18], [9], [19], and a risk factor for perineal tear especially the midline type of episiotomy [20], [12], [14]. Episiotomy is one of the factors identified to increase the risk for Anal sphincter injuries based on a study at Mbarara Hospital [4]. Another risk factor identified was duration of second stage of labour $\geq 1$ hour. In similar study, the protective factors against perineal tear were maternal age of 25 years or more, manual perineal support, and annual income of $\geq 50,000$ Uganda shillings.

Generally, there limited data on risk factors for perineal tears in our setting. Our study aimed at determining the risks factors for perineal tear among women having vaginal delivery at Kawempe National Referral Hospital, Central Uganda. The findings will inform policy formulation and clinical practices geared to enhance better management and prevention of obstetric perineal tear.

\section{Methods}

This was a hospital based un-matched case control study among women who delivered at Kawempe National Referral Hospital (KNRH), central Uganda. The study was conducted from $20^{\text {th }}$ December 2019 to $5^{\text {th }}$ February 2020. KNRH is a public National Referral Hospital specialized in Obstetrics and Gynaecology, Pediatrics and Child health. The hospital serves as a teaching facility for postgraduate trainees in obstetrics and Gynaecology but also for undergraduate medical students of Makerere and St Augustine Universities. Other nearby medical training institution such as Mulago and Mengo school of nursing also use the hospital for teaching. Being a national referral, the hospital is one of the busiest facilities in the country with 80-100 deliveries daily, approximately 32000 deliveries per year. In our study, we defined a case as a mother who either got a second, third or fourth-degree perineal tear during vaginal delivery at $\mathrm{KNRH}$. Controls were mothers who had vaginal delivery at KNRH without getting any perineal tear. We recruited and interviewed 348 participants (116 cases and 232 controls). The sample size was estimated using an online formula for case control study by Glaziou Phillipe [21]. We used primiparity as an independent risk factor based on a study at Tygerberg Hospital in South Africa [22]. The cases were consecutively sampled and for each case, two controls were recruited by considering women who delivered following recruitment of a case. If a case was followed by a case, then the next four women delivering without sustaining a tear were selected as controls. The diagnosis of a case was done by trained research assistants who were professional midwives, with assistance from a residents and 
obstetricians on duty. Data were collected on, social demographic, maternal-obstetric, fetal and provider variables among the study participants. The pretested questionnaires administered by the research assistants were used for data collection. The questionnaires were-checked for completeness and accuracy on daily basis by the first author. Data were double entered and cleaned using Epi data 3.1 and then exported to and analyzed using Stata version 14.1. Using the Chi-square test for categorical variables and Student's t-test for continuous variable, crude odds ratios (CORs) and $p$-values for the variables were determined with their $95 \%$ confidence intervals. The factors with $p$-value of $\leq 0.2$ at bivariate analysis were entered into the multivariate logistic regression model. The adjusted odds ratio (AOR) and P-values for each variable were determined at multivariate level, with statistical significance at a P-value of $\leq 0.05$.

\section{Results}

A total of 348 women (116 cases and 232 controls) were recruited into the study. Of the 116 cases,106 (91.4\%) had second degree tear, $9(7.8 \%)$ third degree tear and $1(0.9 \%)$ fourth degree tear. The participants were aged 14 to 41 years, with mean age of 25.6 years and standard deviation (SD) of \pm 5.6 . Majority of participants were married; $92(79.3 \%)$ of cases and $226(97.4 \%)$ of the controls. The rest of the details are in Table 1. 
Table 1

Socio- Demographic Factors of Study Participants

\begin{tabular}{|c|c|c|c|c|c|}
\hline Variable & $\begin{array}{l}\text { Case, } n= \\
116 / \%\end{array}$ & $\begin{array}{l}\text { Control, } n= \\
232 / \%\end{array}$ & $\begin{array}{l}\text { Crude odds ratio } \\
\text { (COR) }\end{array}$ & $95 \% \mathrm{Cl}$ & $\begin{array}{l}\mathrm{P} \text { - } \\
\text { value }\end{array}$ \\
\hline \multicolumn{6}{|l|}{ Age } \\
\hline$<20$ & $11(9.5)$ & $27(11.6)$ & & & \\
\hline $20-30$ & $92(79.3)$ & $144(62.1)$ & 1.00 & & \\
\hline$>30$ & 13(11.2) & $61(26.3)$ & 1.57 & $0.74-3.31$ & 0.239 \\
\hline \multicolumn{6}{|l|}{ Education } \\
\hline None & $8(7.0)$ & $14(6.0)$ & 1.00 & & \\
\hline Primary & $41(35.6)$ & $70(30.2)$ & 1.03 & $0.40-2.65$ & 0.959 \\
\hline secondary & $50(43.5)$ & $130(56.0)$ & 0.67 & $0.27-1.70$ & 0.403 \\
\hline Tertiary & $16(13.9)$ & $18(7.8)$ & 1.56 & $0.52-4.67$ & 0.431 \\
\hline \multicolumn{6}{|l|}{ Residence } \\
\hline Rural & 16(13.8) & $38(16.4)$ & 1.00 & & \\
\hline Urban & $100(86.2)$ & 194(83.6) & 1.22 & $0.65-2.30$ & 0.530 \\
\hline \multicolumn{6}{|l|}{$\begin{array}{l}\text { Marital } \\
\text { status }\end{array}$} \\
\hline Married & $92(79.3)$ & 226 (97.4) & 1.00 & & \\
\hline Single & $24(20.7)$ & $6(2.6)$ & 9.42 & $\begin{array}{l}3.71- \\
23.88\end{array}$ & $<.001$ \\
\hline \multicolumn{6}{|l|}{ Religion } \\
\hline Catholic & $25(21.6)$ & $60(25.9)$ & 1.00 & & \\
\hline Pentecostal & $38(32.8)$ & $51(22.0)$ & 1.79 & $0.95-3.35$ & 0.070 \\
\hline Muslim & $30(25.9)$ & $59(25.4)$ & 1.22 & $0.64-2.32$ & 0.543 \\
\hline Others & 23(19.8) & $62(26.7)$ & 0.89 & $0.46-1.74$ & 0.733 \\
\hline \multicolumn{6}{|l|}{ Occupation } \\
\hline Employed & 15(12.9) & $21(9.1)$ & 1.00 & & \\
\hline Business & $47(40.5)$ & $85(36.6)$ & 0.77 & $0.36-1.64$ & 0.505 \\
\hline Housewife & 46(39.7) & $111(47.8)$ & 0.58 & $0.28-1.22$ & 0.153 \\
\hline Others & $8(6.9)$ & $15(6.4 \%)$ & 0.99 & $0.29-2.59$ & 0.89 \\
\hline
\end{tabular}


At bivariate analysis (Table 2), women aged above 30 years, single marital status, and Pentecostals were more likely to suffer a perineal tear. Being a house wife was protective against perineal tears. The Obstetric, Antenatal and delivery factors that significantly increased the likelihood for a perineal tear (Table 2 and 3) were: being nulliparous, primiparity, history of perineal tear during a more recent vaginal birth, ANC visit $<4$ times, duration of active first stage of labour $\geq 8$ hours, duration of second stage of labour > 1 hour, precipitate labour, assisted vaginal delivery, and having an episiotomy, fetal birth weight, fetal head circumference, delivery by assistant nursing officer, all significantly increased the likelihood for perineal tear in this context. All variables with a $p \leq 0.2$ at bivariate analysis were entered into multivariate logistic regression model. After testing for interactions and controlling for confounding, statistically significant risk factors are presented in Table 4. The risk factors for perineal tears were: maternal age above 20 years and more $(\mathrm{AOR}=7.2495 \% \mathrm{Cl}=2.28-23.00, \mathrm{P}<0.001)$, delivery by assistant nursing officer $(A O R=16.39,95 \% \mathrm{Cl}=5.74-46.81, \mathrm{p}<0.001)$, primiparity $(\mathrm{AOR}=12.4695 \% \mathrm{Cl} 3.41-45.52)$, a single marital status $(A O R=14.3995 \% \mathrm{Cl}=4.28-48.39 \mathrm{P}<0.001)$. precipitate labour, $(\mathrm{AOR}=7.8,95 \% \mathrm{Cl}=2.21-$ $27.55, \mathrm{P}<0.001)$, assisted vaginal delivery $(\mathrm{AOR}=8.33,95 \% \mathrm{Cl}=1.43-48.6, \mathrm{P}<0.019)$, fetal weight $\geq$ $3.5 \mathrm{Kg},(\mathrm{AOR}=2.19,95 \% \mathrm{Cl}=1.06-4.53, \mathrm{P}<0.033)$, duration of active first stage of labour of $\geq 8$ hours $(A O R=12.65,95 \% \mathrm{Cl}=5.65-28.25 \mathrm{P}<0.001)$ and duration of second stage of labour of $>1$ hour $(\mathrm{AOR}=$ $10.2195 \% \mathrm{Cl}=3.32-31.41, \mathrm{P}<0.001)$ 
Table 2

Bivariate Results of Antenatal Factors for Perineal tears

\begin{tabular}{|c|c|c|c|c|c|}
\hline Variables & $\begin{array}{l}\text { Case, } n= \\
116 / \%\end{array}$ & $\begin{array}{l}\text { Control } n= \\
232 / \%\end{array}$ & $\begin{array}{l}\text { Crude Odds ratio( } \\
\text { COR) }\end{array}$ & $95 \% \mathrm{Cl}$ & $\begin{array}{l}P \text { - } \\
\text { value }\end{array}$ \\
\hline \multicolumn{6}{|l|}{$\begin{array}{l}\text { Number of } \\
\text { pregnancy }\end{array}$} \\
\hline 3 & $66(56.9)$ & $39(16.8)$ & 1.00 & & \\
\hline $2-3$ & $36(31.0)$ & $111(47.9)$ & 1.90 & $\begin{array}{l}0.96- \\
3.75\end{array}$ & $<.064$ \\
\hline$>1$ & $66(56.9)$ & $39(16.8)$ & 9.91 & $\begin{array}{l}4.97- \\
19.79\end{array}$ & $<0.001$ \\
\hline \multicolumn{6}{|l|}{ Parity } \\
\hline 1 & $69(59.5)$ & $39(16.8)$ & 13.45 & $\begin{array}{l}6.24- \\
28.96\end{array}$ & $\begin{array}{l}<.001 \\
0.00\end{array}$ \\
\hline $2-3$ & $37(31.9)$ & $117(50.4)$ & 2.40 & $\begin{array}{l}1.13- \\
5.12\end{array}$ & 0.380 \\
\hline$>3$ & $10(8.6)$ & $76(32.8)$ & 1.00 & & \\
\hline \multicolumn{6}{|c|}{$\begin{array}{l}\text { History of Perineal } \\
\text { tear }\end{array}$} \\
\hline No & $77(67.5)$ & 194(83.6) & 1.00 & & \\
\hline Yes & $37(32.5)$ & $38(16.4)$ & 0.63 & $\begin{array}{l}0.34- \\
1.15\end{array}$ & 0.131 \\
\hline \multicolumn{6}{|c|}{ Antenatal ANC } \\
\hline Yes & 115 (99.1) & $222(96.1)$ & 0.19 & $\begin{array}{l}0.11- \\
0.33\end{array}$ & $<0.001$ \\
\hline No & $1(0.9)$ & $1(3.9)$ & 0.10 & $\begin{array}{l}0.05- \\
0.20\end{array}$ & \\
\hline \multicolumn{6}{|c|}{$\begin{array}{l}\text { Number of ANC } \\
\text { visits }\end{array}$} \\
\hline$<4$ visits & $50(43.1)$ & $124(53.5)$ & 1.00 & & \\
\hline$\geq 4$ visits & $25(21.6)$ & $29(12.5)$ & 0.18 & $\begin{array}{l}0.10- \\
0.31\end{array}$ & $<0.001$ \\
\hline \multicolumn{6}{|l|}{$\begin{array}{l}\text { Pregnancy } \\
\text { intervals }\end{array}$} \\
\hline$<2$ year & 23(39.0) & $56(28.6)$ & 1.000 & & \\
\hline$\geq 2$ years & $36(61.0)$ & 140(71.43) & 0.382 & 0.240 & 0.609 \\
\hline
\end{tabular}




\begin{tabular}{|llllll|}
\hline Variables & $\begin{array}{l}\text { Case, } n= \\
116 / \%\end{array}$ & $\begin{array}{l}\text { Control } n= \\
\mathbf{2 3 2 / \%}\end{array}$ & $\begin{array}{l}\text { Crude Odds ratio( } \\
\text { COR) }\end{array}$ & $95 \%$ Cl & $\begin{array}{l}\text { P- } \\
\text { value }\end{array}$ \\
\hline $\begin{array}{l}\text { Herbal medicine } \\
\text { use }\end{array}$ & & & & & \\
\hline Yes & $110(94.8)$ & $219(94.8)$ & 1.00 & $0.36-$ & 0.993 \\
\hline No & $6(5.2)$ & $12(5.2)$ & 0.99 & 2.72 & \\
\hline BMI & & & & & \\
\hline$<18.5$ & $1(0.9)$ & $1(0.4)$ & 1.00 & $0.12-$ & 0.642 \\
\hline $18.5-24.9$ & $35(30.2)$ & $68(29.3)$ & 1.94 & 32.00 & \\
\hline $25-29.9$ & & & & $0.56-$ & 0.802 \\
\hline $30.0-39.9$ & $51(44.0)$ & $106(45.7)$ & 0.93 & $0.54-$ & 0.97 \\
\hline
\end{tabular}


Table 3

Bivariate Results of Obstetric Risk Factors for Perineal tear.

\begin{tabular}{|c|c|c|c|c|c|}
\hline Variables & $\begin{array}{l}\text { Case, } n= \\
116 / \%\end{array}$ & $\begin{array}{l}\text { Control } \\
n= \\
232 / \%\end{array}$ & $\begin{array}{l}\text { Crude Odds ratio( } \\
\text { COR) }\end{array}$ & $95 \% \mathrm{Cl}$ & $\begin{array}{l}\mathrm{P}- \\
\text { value }\end{array}$ \\
\hline \multicolumn{6}{|c|}{$\begin{array}{l}\text { Duration of second } \\
\text { stage }\end{array}$} \\
\hline$<30$ minutes & $55(47.1)$ & $196(84.5)$ & 1.00 & & \\
\hline $30-60$ minutes & $32(27.6)$ & $29(12.5)$ & 1.42 & $0.61-3.33$ & 0.414 \\
\hline$>60$ minutes & $29(25.0)$ & $7(3.0)$ & 10.21 & $\begin{array}{l}3.32- \\
31.41\end{array}$ & $\begin{array}{l}<.001 \\
0.0\end{array}$ \\
\hline \multicolumn{6}{|c|}{ Precipitate Labour } \\
\hline NO & $107(92.2)$ & $224(96.6)$ & 1.00 & & \\
\hline Yes & $9(7.8)$ & $8(3.5)$ & 2.36 & $0.88-6.27$ & 0.087 \\
\hline \multicolumn{6}{|l|}{ Oxytocin Use } \\
\hline Yes & $67(51.0)$ & $110(47.4)$ & 1.00 & & \\
\hline No & $48(42.0)$ & $122(52.6)$ & 0.07 & $0.02-0.25$ & ¿. 001 \\
\hline \multicolumn{6}{|l|}{$\begin{array}{l}\text { Assisted Vaginal } \\
\text { Delivery }\end{array}$} \\
\hline No & $98(84.5)$ & $229(99.1)$ & 1.00 & & \\
\hline Yes & 18(15.5) & $2(0.9)$ & 14.02 & $\begin{array}{l}4.04- \\
48.69\end{array}$ & $\hat{0.001}$ \\
\hline \multicolumn{6}{|l|}{ Episiotomy } \\
\hline No & $82(70.7)$ & $42(81.9)$ & 1.00 & & \\
\hline Yes & $34(29.3)$ & 190(18.1) & 1.88 & $1.11-3.16$ & 0.018 \\
\hline \multicolumn{6}{|c|}{ Birth weight of baby } \\
\hline$<3.5 \mathrm{~kg}$ & $75(64.7)$ & 177(76.3) & 1.00 & & \\
\hline$\geq 3.5 \mathrm{Kg}$ & $41(35.3)$ & $55(23.7)$ & 1.76 & $1.08-2.86$ & 0.023 \\
\hline \multicolumn{6}{|c|}{$\begin{array}{l}\text { Head } \\
\text { circumference(cm) }\end{array}$} \\
\hline$<35.0$ & $72(62.1)$ & $167(72.0)$ & 1.00 & & \\
\hline$\geq 35.0$ & $44(37.9)$ & $65(28.0)$ & 1.57 & $0.98-2.52$ & 0.061 \\
\hline
\end{tabular}




\begin{tabular}{|c|c|c|c|c|c|}
\hline Variables & $\begin{array}{l}\text { Case, } n= \\
116 / \%\end{array}$ & $\begin{array}{l}\text { Control } \\
n= \\
232 / \%\end{array}$ & $\begin{array}{l}\text { Crude Odds ratio( } \\
\text { COR) }\end{array}$ & $95 \% \mathrm{Cl}$ & $\begin{array}{l}\mathrm{P}- \\
\text { value }\end{array}$ \\
\hline \multicolumn{6}{|l|}{ Birth attendant } \\
\hline Enrolled midwives & $78(67.2)$ & 217(93.5) & 1.00 & & \\
\hline $\begin{array}{l}\text { Assistant Nursing } \\
\text { Officer }\end{array}$ & $36(31.0)$ & $8(3.5)$ & 12.52 & $\begin{array}{l}5.58- \\
28.10\end{array}$ & $<0.001$ \\
\hline Student & $2(1.7)$ & $6(2.6)$ & 1.00 & & \\
\hline \multicolumn{6}{|l|}{ Labour onset } \\
\hline Spontaneous & 112(96.6) & 228(98.3) & 1.00 & & \\
\hline Induced & $4(3.4)$ & $4(1.7)$ & 2.04 & $0.50-8.29$ & 0.31 \\
\hline \multicolumn{6}{|l|}{ Method of induction } \\
\hline Oxytocin & $2(33.3)$ & 1(33.3) & 1.00 & & \\
\hline Prostaglandins & $4(66.7)$ & $2(66.7)$ & 1.00 & $\begin{array}{l}0.05- \\
18.91\end{array}$ & 1.000 \\
\hline \multicolumn{6}{|c|}{ Active labour duration } \\
\hline Less than 8hours & $55(47.4)$ & 209(90.1 & 1.00 & & \\
\hline 8 hours or more & $61(52.6)$ & 23(9.9) & 10.08 & $\begin{array}{l}5.73- \\
17.72\end{array}$ & $\hat{0.001}$ \\
\hline
\end{tabular}


Table 4

Multivariate Analysis for Risk Factors of Risk Factors for Perineal tear

\begin{tabular}{|c|c|c|c|c|}
\hline Variable & $\begin{array}{l}\text { Crude odd's ratio } \\
\text { (COR) }\end{array}$ & $\begin{array}{l}\text { Adjusted odd's ratio } \\
\text { (AOR) }\end{array}$ & $95 \% \mathrm{Cl}$ & $\begin{array}{l}P \\
\text { value }\end{array}$ \\
\hline \multicolumn{5}{|l|}{ Age } \\
\hline$<20$ & 1.00 & 1.00 & & \\
\hline $20-30$ years & 1.57 & 7.24 & $\begin{array}{l}2.28- \\
23.00\end{array}$ & 0.001 \\
\hline More than 30 years & & 7.83 & $\begin{array}{l}1.63- \\
37.54\end{array}$ & 0.001 \\
\hline \multicolumn{5}{|l|}{ Birth attendant } \\
\hline Enrolled midwife & 1.00 & 1.00 & & \\
\hline Assistant Nursing officer & 12.52 & 16.39 & $\begin{array}{l}5.74- \\
46.81\end{array}$ & $<.001$ \\
\hline Students & 0.93 & 0.59 & $\begin{array}{l}0.07- \\
5.33\end{array}$ & 0.639 \\
\hline \multicolumn{5}{|l|}{ Parity } \\
\hline$>3$ & 1.00 & 1.00 & & \\
\hline $2-3$ & 2.40 & 1.67 & $\begin{array}{l}0.53- \\
5.30\end{array}$ & $<.380$ \\
\hline 1 & 13.45 & 12.46 & $\begin{array}{l}3.41- \\
45.52\end{array}$ & $\begin{array}{l}<.001 \\
0.01\end{array}$ \\
\hline \multicolumn{5}{|l|}{ Marital Status } \\
\hline Married & 1.00 & 1.00 & & \\
\hline Single & 9.42 & 14.39 & $\begin{array}{l}4.28- \\
48.39\end{array}$ & $\begin{array}{l}<.001 \\
0.001\end{array}$ \\
\hline \multicolumn{5}{|l|}{ Precipitate Labour } \\
\hline No & 1.00 & 1.00 & & \\
\hline Yes & 2.36 & 7.80 & $\begin{array}{l}2.21- \\
27.55\end{array}$ & $\begin{array}{l}< \\
0.001\end{array}$ \\
\hline \multicolumn{5}{|l|}{$\begin{array}{l}\text { Assisted Vaginal delivery } \\
\text { (AVD) }\end{array}$} \\
\hline No & 1.00 & 1.00 & & \\
\hline Yes & 14.02 & 8.33 & $\begin{array}{l}1.43- \\
48.60\end{array}$ & 0.019 \\
\hline
\end{tabular}




\begin{tabular}{|lllll|}
\hline Variable & $\begin{array}{l}\text { Crude odd's ratio } \\
\text { (COR) }\end{array}$ & $\begin{array}{l}\text { Adjusted odd's ratio } \\
\text { (AOR) }\end{array}$ & $95 \%$ Cl & $\begin{array}{l}\text { P } \\
\text { value }\end{array}$ \\
\hline Birth Weight & 1.00 & & & \\
\hline$<3.5 \mathrm{Kg}$ & 1.76 & 1.00 & $1.06-$ & 0.033 \\
$\geq 3.5 \mathrm{Kg}$ & 2.19 & 4.53 & \\
\hline $\begin{array}{l}\text { Duration of Active stage } \\
\text { labour }\end{array}$ & 1.00 & & & \\
\hline$<8$ hours & 17.58 & 1.00 & $5.65-$ & $<$ \\
\hline$\geq 8$ hours & & 12.65 & 28.25 & 0.001 \\
\hline $\begin{array}{l}\text { Duration of second stage of } \\
\text { labour }\end{array}$ & & & & \\
\hline$<30$ minutes & 1.00 & 1.00 & & \\
\hline $30-60$ & 3.93 & 1.42 & 3.33 & 0.414 \\
\hline$>60$ & 14.76 & 10.21 & $3.32-$ & $<0.001$ \\
\hline
\end{tabular}

\section{Discussion}

This was an index case control study on risk factors for perineal tear in our setting of $\mathrm{KNRH}$. The risk factors for perineal tear in this setting were- maternal age of 20 years or more, primiparity, a single marital status of a woman, precipitate labour, assisted vaginal delivery, fetal weight $\geq 3.5 \mathrm{~kg}$, active first stage of labour $\geq 8$ hours, second stage of labour duration $>1$ hour and delivery by assistant nursing officer. In our study, women who were aged 20 -30 years were 7.2 times more likely to get a perineal tear during vaginal delivery, compared to those below 20 years. The risk was even greater for women aged more than 30 years (AOR= 7.83). The results could be due to reduced distensibility during labour and delivery among parturients 20-30 years of age. With advancing age reduction in estrogen levels of a woman has been linked to qualitative reduction of perineal muscle strength, hence the likelihood of sustaining a tear [23]. Advanced maternal age as risk factor for perineal tear has been reported in other studies [24], [25]. The observation highlights the need for vigilance on preventive measures and special precautions during delivery for women risk.

Marital status was a significant risk factor. In this case being single was a risk factor for perineal tear. The likelihood of experiencing a perineal tear was 14.39 times among women of a single marital status 
compared to those who were married. This could be due to the fact that women who are unmarried are deprived of the psychosocial, emotional and economical support during pregnancy, labour and delivery resulting into anxiety, stress, loss of confidence and tension during throughout pregnancy and labour. Maternal anxiety and tension has been associated with increased risk for perineal tear due to increased tension in the pelvic muscles [8], [16].

Primiparity was a risk factor for perineal tear. The risk for perineal tear was 12.46 times more likely when a woman was primiparous compared to a multiparous counterpart. This could be due to minimal level of elasticity and flexibility among nulliparous compared to the multiparous group [26]. The observation highlights the need to sensitize all primiparous women during ANC about the importance of delivering under a skilled birth attendant. Several other studies have reported similar findings [6], [27], [25].

Precipitate labour was risk factor for perineal tear. This has been attributed to the fact that rapid labour progression provides no room for sufficient distension and compliance of the perineum [16]. The findings highlight the need for health workers to anticipate and diagnose precipitate labour promptly for timely preventive measures. This observation was also reported in others studies [13], [16].

Also, assisted vaginal delivery was identified as a risk factor. The odds of getting a perineal tear was 8.33 times when a woman had vacuum assisted delivery compared to a normal delivery. This could be attributed to the mechanical effect of the device to the perineum during extraction of the fetal head. The outcome could also dependent on to the user technique and experience. Inappropriate placement and choice of the cup type and size has been associated with high failure rates and perineal injury [28]. This observation highlights the need for good skills and precautions while conducting the procedure. The findings were in agreement with reports from other studies [6], [9], [29].

Newborn birth weight of $\geq 3.5 \mathrm{~kg}$ was a risk factor. The risk of getting a perineal tear was 2.19 times more likely when fetal weight was $\geq 3.5 \mathrm{~kg}$. This could be due to the increased likelihood of cephalopelvic disproportion associated with a big fetus. The findings remind us of the need to always estimate the fetal weight during antenatal clinic visits, labour and time of admission.

Understanding the estimated fetal weight before delivery allows special precautions against perineal tears. Furthermore, a decision may be made to deliver a mother with fetal macrosomia by caesarean section. Similar findings have been reported in other studies [30], [10].

Duration of active first stage of labour $\geq 8$ hours was a risk factor for perineal tear. The odds for sustaining a perineal tear was 15 times more likely when active first stage of labour was $\geq 8$ hours. Protracted labour duration has been associated with reduced optimal tissue distention and compliance, hence the observed odds for perineal injury [16]. The findings highlight the need for a mandatory, effective monitoring of labour progress with partograph and timely interventions. The possible interventions could be fluid administration, rupture of membranes, bladder drainage among others. Similar findings have been reported in other studies [11], [16] . 
Duration of second stage of labour $>1$ hour was also a risk factor for perineal tear. The odds of having a perineal tear was 10 times higher when second stage of labour exceeded one hour. This could be explained by the increase of genital tract edema which prevents optimal distention and compliance during descent of the presenting part [16]. This observation has clinical implications regarding current clinical practices as it highlights the need for effective monitoring of all mothers in labour. The close monitoring is to allow timely diagnosis of abnormal progress for specific intervention. Similar findings were also highlighted in several studies [11], [9], [10].

Delivery by assistant nursing officer (Nursing Officer); was an independent risk factor for perineal tear. This could be due to the fact that highly qualified midwives tend to handle the more complicated referred cases hence exposed to interventions known to carry extra risk for tears. In our setting, most pregnant women who are referred, tends to undergo obstetric interventions such as labour augmentation with oxytocin, episiotomy or instrument delivery which further increases their risk for perineal tear [9]. Important to note, personal behavior, altitude, skills and experience a birth attendant in this context could influence the delivery outcomes. Hence, although well qualified, assistant nursing officers may not have the relevant experience in midwifery compared to their counterparts (enrolled midwives). The findings highlight the need to provide continuous medical education to health workers in this context. This was contrary to previous studies where high qualification was associated with reduced risk for perineal tear [31], [8], [11].

Our study revealed that augmentation of labour with oxytocin was not a risk factor for perineal tear contrary to other studies [5]. This was concurrent to other studies [32], [27]. However, another study with a large sample size may be conducted to determine the effect of oxytocin augmentation of labour on occurrence of perineal tears. Also episiotomy was not a risk factor for perineal tear contrary. The observation was concurrent with other studies which highlighted that episiotomy especially the mediolateral episiotomy was protective against perineal tear [9], [18]. Also, fetal head circumference $\geq$ $35 \mathrm{~cm}$ was not a risk factor for perineal tears. The results were contrary to studies done in other countries [33], [34]. This was a surprise finding because a large head circumference would be expected to increase risk of perineal injuries. Another study with larger sample size could be conducted to evaluate effect of head circumference on perineal tears.

\section{Study limitations}

It was difficult to establish a significant relationship for some variables such as face presentation occiput posterior due to lack of enough power. Previous studies have indicated that these factors increase the risk for perineal tear. Also being a hospital-based study, most of the patients were referrals so the findings may not be generalizable to the entire county population.

\section{Conclusions}


The risk factors for perineal tear among women delivering at Kawempe National Referral Hospital arematernal age of above 20 years and more, being primiparous, single marital status, precipitate labour, assisted vaginal delivery, fetal weight $\geq 3.5 \mathrm{~kg}$, duration of active first stage of labour $\geq 8$ hours, duration of second stage of labour of $>1$ hour and delivery by assistant nursing officer. We recommend $\mathrm{CME}$, coaching, technical support supervision on effective monitoring of labour with a mandatory third trimester ultrasound scan before labour onset to estimate the fetal weight. Every mother should have an estimated fetal weight documented on her clinical chart at labour onset. Evidence based preventive measures for perineal tear such as manual perineal support, should be used where appropriately to protect the perineum during labour. Another case control study with larger sample size could be conducted to evaluate effect of head circumference of perineal tears.

\section{Abbreviations}

\begin{tabular}{ll} 
CME & Continous Medical Education \\
\hline ANC & Antenatal Care \\
\hline AOR & Adjusted Odd's Ratio \\
\hline $\mathrm{Cl}$ & Confidence Interval \\
\hline OR & Odd's Ratio
\end{tabular}

\section{Declarations}

\section{Ethical Approval and Consent to Participate.}

The study was approved by the School of Medicine Research and Ethics Committee of Makerere University (\# REC REF 2019-161). Permission to conduct the study was obtained from administration of Kawempe National Referral Hospital. Written informed consent was obtained from each study participant and legal guardians or parents consented for minors. All methods were perfomed in accordance with the relevant guidelines and regulations

\section{Consent for publication.}

Not applicable

\section{Availability of data and materials.}

All data generated or analysed during this study are included in this published article ( and its supplementary information files) 


\section{Competing Intrests.}

The authors declares that they have no competing intrests in regard to the study.

\section{Funding.}

The study was financed by the first author (corresponding author) with no external funding.

\section{Authors Contributions.}

GM conceived the initial idea of the study, spearheaded the study design, participated and supervised data collection process, wrote the manuscript.

BJK, supported the first author to develop the study design, read and agreed to submit the final manuscript

KL Supervised, data collection, read and agreed to submit the final manuscript

\section{Acknowledgements}

We thank the research assistants involved in data collection, the women who participated in the study, $\mathrm{Dr}$ Wani Muzei statistician, for advice on refining the statistical model and interpretation of the findings. Permmision for acknowledgement was obtained from all individuals being acknowledged under this section.

\section{References}

1. Kettle C , T.S., Perineal care, Stoke, UK. BMJ Clin Evid., 2008. 2008(1401).

2. Goh Ryan , D.G., Hasthika Ellepola, Perineal tears- A review, Melbourne, Austraria,.AJGP, 2018. 47(1-2).

3. Katariina Lane , S., F,N, Leiv Sandvik, Anne Catherine S, Incidence of Obstetric Anal Sphincter Injuries after training to protect the perineum: Acohot study in Oslo, Norway.BMJ,2012. 2.

4. Mahad Ali, R.M., Joseph Ngonzi, Joy Muhumuza, Ronald Mayanja, et al., Risk Factors for Obstetric Anal Sphincter Injuries among Women Delivering at a Tertiary Hospital in Southwestern Uganda, Mbarara. International Journal of Gynaecology and Obstetrics., 2020.

5. RCOG., The Management of Third and Fourth Degree Perineal tears.. 2015.

6. Hirayama F, K.A., Mori R, Zhanga J, Souza JP, Gülmezoglu AM,, Prevalence and risk factors for thirdand fourth-degree perineal lacerations during vaginal delivery: a multi- country study,. BJOG, 2012. 
119(3): p. 340-347.

7. Kigonya, K., The prevalence and factors associated with perineal tears among mothers undergoing vaginal delivery at Mulago National Referral Hospital. Unpublished master's thesis, Makerere University, Kampala, Uganda. 2014.

8. Lindgren, H.E., Brink, A., Klingberg-Allvin, M., Fear causes tears- Perineal injuries in home birth settings. A Swedish interview study, Gothemburg, Sweden. BMC Pregnancy Childbirth, 2011. 11(6).

9. Lesley A Smith, N.P., Ethel E Burns, Simonite, Incidence of and risk factors for perineal trauma: a prospective observational study, Oxford, UK. BMC Pregnancy and Child Birth, 13(59).

10. Alice Cola , S.M., Debora Verri, Maria Lieta Interdonato, Elena Nicoli, Martina, et al, Third and fourth degree perineal tears: Incidence and risk factors in an Italian setting, University of Milano-Bicocca Italy. Euro J Obstet Gynaeco Reprod Biol, 2016. 206(27).

11. Wu Hsieh Chiao, C.C.L., Dennis Wu, Shuenn-Dhy Chang, Ho-Yen Cheh, An-Shine Chao, Prevalence and contributing factors of severe perineal damage following episiotomy assisted vaginal delivery, Taoyuan, Taiwan. Taiwanese Journal of Obstetrics and Gynaecology,, 2014. 53(1): p. 481-485.

12. Grazyna Gebuza, m.K., Alicja Gdaniec, Estera Mieczkowska, Malgorzata Gierzewska, Episiotomy and Perineal tear risk factors in a group of 4493 women, Tourn, Poland,.Health Care for Women International, 2018. 39(6, ).

13. Melamed N, G.O., Eisne M, Wiznitzer A, Wasserberg N, Yogev $Y_{\text {, }}$ Third and Fourth degree Perineal Tears-Incidence and and Risk Factors, Tel Aviv, Israel. j Maternal Fetal Neonatal Medicine, 2013. 26(7): p. 660-664.

14. Groutz A, C.A., Gold R, Hasson J, Wengier A, Lessing JB, et al, Risk factors for severe perineal injury during childbirth: a case-control study of 60 consecutive cases, in Tel Aviv, Israel. 2011.

15. Sultan AH, K.M., Hudson CN, Bartram Cl., Third degree obstetric anal sphincter tears risk factors and outcome of primary repair, London, UK. BMJ, 1994. 308(6933): p. 887-891.

16. 16. Fouelifack F Y, E.F., Kemadjou LT, Fouedijio J H, Mbu, R, Fouogue J T, et al. Risk Factors of Genital Tract Lacerations at Yaounde Central Hospital-Cameroon: A case Control Study. Journal of Advances in Medicine and Medical Research, 2017. 20(2).

17. Yuval Lavy, S.K.P., Kaniel Chava, Celnikier Hochner D., Can Pelvic Floor Injury secondary to Delivery be prevented, Jerusalem, Israel. International Urognaecology Journal, 2011.23(2): p. 165-173.

18. Shimaa Mosad Mohamed, N.y.A., Maher Shams Elden Hassan ,Nahed Fikry Hassan Khedr., Practices that Apllied on protection of the perineal trauma among Parturient Women: A cross sectional study, Mansouta, Egypt, . Journal of Nursing and Health Science 6(5): p. 88-95. Panuela Ivan, N.P.I., Tamayo 
Eduardo, Epidural analgesia and its implications in the maternal health in a low parity community, Torragona, Spain. BMC Pregnancy and Child Birth, 2019. 19(52).

20. Gurol-Urgacil I, C.D., Edozien LC, et al., Third and Fourth degree perineal tears among primiparous women in England between 2000 and 2012: Time trends and risk factors, London ,England. BJOG, 2013. 120(12): p. 1516-1525.

21. http://sampsize.sourceforge.net/iface/s3.html, G.P., 2005.

22. Leonard Juul, G.B.T.-. Risk factors for third and Fourth Degree Perineal Tears During Delivery, Cape Town ,South Africa. Urogynaecologia 2011. 25.

23. Dawn A. Lowe, K.A.B., Sarah M. Greising, Mechanisms behind Estrogen's beneficial effect on muscle Strength in female, Minnesota, USA. PMC, 2011. 38(2): p. 61-67.

24. Waldenstrom, U., Ekeus C, Risk of obstetric anal sphincter injury increases with maternal age irrespective of parity: a Population based register study, Stockolm, Sweden. BMC Pregnancy and Child Birth, 2017. 17(306).

25. Amadeus Hornemann, A.K., Doerte W Luedders, D.A Beyer, Advanced age is a risk factor for higher grade perineal lacerations during delivery in nulliparous women. 2009.

26. Nakamura U M, S.N., Zanetti Raque M D, Parturient Perineal distensibility tolerance asssed by EPI-NO: an observational study, Sao Paul, Brazil. Einstein 2014. 12(1):p.22-26.

27. 27. Eskandar O, S.D., Risk Factors for 3rd and 4th Degree Perineal tear, Burnstape, UK. J Obstet Gynaecol, 2009. 29(2): p. 119-122.

28. Sau. A, S., M, Ahmed ,H, Brown, R., Vacuum extraction: is there any need to improve the current training in the UK?, Gillingham, Farnborough, UK. Acta obstet Gynaecol Scand, 2004. 83: p. 466-470.

29. Marija Simic, S.C., Olof Stephanson, et al., Duration of second stage of labor and instrument delivery as a risk factor for severe perineal lacerations: Population based study, 2008-2014, Stochholm Sweden. BMC Pregnancy and Child Birth, 2017. 17(72).

30. Egbe TO KL, T.W., Tchounzou R et al., Prevalence and Risk Factors For Perineal Tears at the Limbe Regional Hospital, Buea, Cameroon. 2016.

31. Johannes Ott, E.G., Pils S, Kratschmar S, A retrospective study on perineal lacerations in vaginal delivery and the individual perfomance of experienced midwives, Vienna, Austria.BMC Pregnancy and Child Birth, 2015. 15(1): p. 270.

32. Al Ghamdi T, H.A.T.A., Talal Chamsi A, Al Mardawi E, Incidence and Risk Factors for Development of Third and Fourth Degree Perineal Tears: A Four Year Experience in aSingle Saudi Center. 2018. 
33. Egbe TO, K.L., Tang WA, Tchounzou R, Egbe EN, et al., Prevalence and Risk Factors for Perineal Tears at Limbe Regional Hospital, Yaounde Cameroon. Int J Reprod Fertil Sex Health 3(3): p. 70-78.

34. Jansova M, K.V., Rusavy Z, Raisanen S, Lobovsky L, Laine K, Fetal head size and effect of manual perineal protection, Prague, Czech Republic. PLoS One, 2017. 12(12).

\section{Supplementary Files}

This is a list of supplementary files associated with this preprint. Click to download.

- TABLES1.docx 